to other spectrometers. The main defect is an apparent lack of editing and co-ordination in producing the book from the material presented at the 'workshop'; the repetition which is acceptable and desirable in a lecture series is less welcome in a book. Basic topics are described with increasing detail but with considerable overlap on passing through the various chapters of Part 1 to Parts 2 and 3, and, for example, the same photograph of a high-resolution nuclear magnetic resonance spectrometer appears three times in Part 1, and similar drawings of the spectral shape produced by 'dished' and 'domed' magnetic fields occur on pp. 60 and 95 .

In short, the book contains good material but is badly edited. It can be recommended to all who need a general introduction to the field, and should be particularly valuable to those who want some insight into the experimental problems involved in the operation of spectrometers.

R. K. WeBster

\section{DEEP-SEA MICROBIOLOGY}

Meeres-Mikrobiologie

Tiefseeforschungen. Von Prof. Dr. A. E. Kriss. Pp. ix +570. (Jena: Gustav Fischer Verlag, 1961.) 98.10 D.M.

T $\mathrm{T}$ has long been recognized that Russian investiga1 tors have played an important part in the development of the science of marine microbiology. It is unfortunate, however, that owing to language difficulties and the relative inaccessibility of many of their journals and monographs, their results have remained comparatively unknown to most workers outside the U.S.S.R. The appearance of another book on marine, and in particular on deep-sea, microbiology where so few already exist would in itself be an event, but where it also summarizes the tremendous volume of recent Russian work in this field it is doubly welcome. The present volume is a revised German edition of the 1959 Russian one which gained for its author a Stalin prize. A more thoroughly revised English version is due to appear shortly.

In 1947 the Institute of Microbiology of the Academy of Sciences of the U.S.S.R. organized a series of investigations into the microbiology of the deep layers of the various seas and oceans. This was in contradistinction to most of the previous work, both inside and outside the U.S.S.R., which dealt mainly with surface waters and the continental shelf, and which was so ably summarized by ZoBell in his Marine Microbiology (1947). Commencing with the Black Sea, these Russian investigations have virtually covered every major sea and ocean from the Arctic to the Antaretic, allowing comparison to be made between various types of marine basins-the Black Sea, an intra-continental deep-sea basin; the Caspian, the largest sea-lake; the Pacific, in regions containing the deepest trenches in the world; the Arctic, with its perennial covering of pack ice: and the results to date have now been ably summarized by Prof. Kriss.

Descriptions are given of the methods, both quantitative and qualitative, used for investigating water masses in depth including two pioneered in this sphere by Kriss and his colleagues, namely, the submerged-slide and membrane-filter techniques. As a result, we have for once a composite picture of the vertical and horizontal distribution of bacterial populations throughout tho world's seas and oceans, including the effects thereon of various seasonal, geographical and other factors. Two long chapters are devoted to descriptions of the various species of bacteria, yeasts and actinomycetes encountered and their morphological variations, both vertical and horizontal. Some of these organisms are new to science, for example, the class of Krassilnikoviae, of which some excellent microphotographs are provided.

Having described both qualitatively and quantitatively the microflora, and also their general biochemical propensities in transforming a great variety of substances in sea and oceans, Kriss then attempts to give some idea of the microbial biomass in these water basins, utilizing to the full the direct-count and membrane-filter techniques, although some may doubt the reliance placed on these by Russian workers. Data indicate that the greatest microbial concentrations occur in certain layers in the Caspian Sea (approximately $250,000 / \mathrm{ml}$. or a biomass of 45 mgm. $/ \mathrm{m}^{3}$ ) followed by the Black Sea and the Pacific in the area of the Kuril Islands. In the North Polar Sea, even at the season of maximal activity the counts and biomass are approximately only $1 / 10$ $1 / 20$ of those of the Caspian.

To many readers, the final chapters on microorganisms in relation to the biological productivity of the ocean, and as indicators of hydrological phenomena, will be of most interest. Kriss maintains that insufficient account has been taken of the importance of micro-organisms for investigating problems of biological activity in aquatic environments, as, for example, in their role in providing, in themselves, food for young fish and in producing vitamins and other biologically active substances. With regard to the use of micro-organisms as hydrological indicators, Kriss obviously believes that they can be of immense value for the study of the dynamics and origin of water masses and for indicating deep currents at present poorly defined by other methods. By the use of micro-organisms, Kriss has been able to substantiate and extend the more widely accepted views concerning the general hydrography of world oceans as expounded by Sverdrup, Johnson and Fleming (The Oceans; Their Physics, Chemistry and General Biology: New York, 1942), although on occasions he has seemed to differ considerably from these experts.

In a volume such as this, full of interesting and often arresting facts and information in almost every page, it is difficult to be critical. The major fault appears to be the almost superabundance of data, so that one cannot see the wood for the trees. There appears to be a reiteration of material in different chapters. The long, detailed Chapter 3, describing the biochemical, morphological and other properties of the various species isolated, seems out of place in this type of book, and could well have been combined with Chapter 6, also dealing with the morphological characteristics of micro-organisms. Moreover, it is unfortunate that Krassilnikov's Determinative Key for Bacteria and Actinomycetes (Moscow, 1949), known to few outside the U.S.S.R., should have been used for purposes of classification.

Despite these criticisms, the book should be read by all interested in marine science, because none by previous authors contains anything approaching the amount of data collected here. It is well produced and fully documented, and lavishly illustrated with figures, diagrams and photographs, and deserves to become widely known.
J. M. SHEWAN 